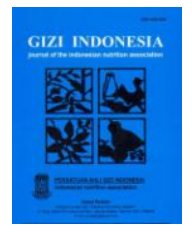

Journal of The Indonesian Nutrition Association

p-ISSN: 0436-0265 e-ISSN: 2528-5874

http://ejournal.persagi.org/ojspersagi2481/index.php/Gizi_Indon

\title{
PENGARUH PENAMBAHAN MALTODEKSTRIN DALAM MINUMAN ELEKTROLIT TERHADAP DAYA TAHAN JANTUNG PARU ATLET SEPAK BOLA
}

\author{
Effect of Maltodextrin Adding in The Electrolyte Drinks on Cardiorespiratory \\ Endurance of Soccer Athletes During Exercise
}

\author{
Nur Amin ${ }^{1,4}$, Hardhono Susanto', M. Zen Rahfiluddin ${ }^{3}$ \\ 1Program Studi Magister IImu Gizi, Fakultas Kedokteran, Universitas Diponegoro, Semarang, Indonesia \\ 2Program Studi Anatomi, Fakultas Kedokteran \\ 3Program Studi Gizi, Fakultas Kesehatan Masyarakat \\ 4Program Studi S1 Gizi, Fakultas Kesehatan, Universitas Nahdlatul Ulama Surabaya, Indonesia \\ E-mail: nuramin@unusa.ac.id
}

\begin{abstract}
Maximum exercise, hydration status, and good nutrition intake could improve the cardiorespiratory endurance. The aim of this study was to analyzed the effect of maltodextrin adding in the electrolyte drinks on cardiorespiratory endurance of soccer athletes during exercise. This quasi-experimental study used a crossover design on 17 soccer athletes of Central Java PPLP in 2015. The study lasted in six weeks periods, during the exercise athletes were given $4 \times 300 \mathrm{~mL}$ drink at $30,60,90$, and 120 minutes continued with cardiorespiratory endurance test. The control group was given only an electrolyte drink whereas the treatment group was given an electrolyte drink adding with 18 grams of maltodextrin. Measurements included body weight, body height, BMI, body fat percetage, BMR, minerals and macro nutrient intake, and cardiorespiratory endurance. The result shows cardiorespiratory endurance of soccer athletes after giving maltodextrin increase significantly $(51.0 \pm 3.16$ to $51.6 \pm 3.28 \mathrm{~mL} / \mathrm{kg} \mathrm{BW} / \mathrm{min})$ $(p=0.001)$. The result shows that increasing of the cardiorespiratory endurance in treatment group $(0.6 \pm$ $0.80 \mathrm{~mL} / \mathrm{kg} \mathrm{BW} / \mathrm{min})$ is significantly higher than control group $(0.2 \pm 0.15 \mathrm{~mL} / \mathrm{kg} \mathrm{BW} / \mathrm{min})$ is shown with $p=0.02$. BMI, fat mass percentage, BMR, minerals and macro nutrient intake have no correlation with cardiorespiratory endurance. It can be concluded that the giving of maltodextrin as much as $4 \times 18 \mathrm{~g}$ in $4 \times 300 \mathrm{~mL}$ electrolyte drinks increase the cardiorespiratory endurance of soccer athletes during exercise.
\end{abstract}

Keywords: maltodextrin, cardiorespiratory endurance, soccer athletes

\section{ABSTRAK}

Latihan maksimal, status hidrasi, dan pemenuhan kebutuhan gizi yang baik dapat meningkatkan daya tahan jantung paru. Tujuan penelitian ini untuk menganalisis pengaruh penambahan maltodekstrin dalam minuman elektrolit terhadap daya tahan jantung paru atlet sepak bola selama latihan. Penelitian ini adalah quasy experimental dengan desain crossover pada 17 atlet PPLP sepak bola Jawa Tengah Tahun 2015. Penelitian berlangsung selama 6 minggu, pada saat latihan atlet diberikan minuman elektrolit sebanyak $4 \times 300 \mathrm{~mL}$ pada menit ke-30, 60, 90 dan 120 kemudian dilakukan tes daya tahan jantung paru. Kelompok perlakuan diberikan minuman elektrolit yang ditambah $4 \times 18 \mathrm{~g}$ maltodekstrin sedangkan kelompok kontrol hanya diberikan minuman elektrolit. Pengukuran yang dilakukan pada penelitian ini meliputi berat badan, tinggi badan, IMT, persentase lemak tubuh, BMR, asupan mineral dan zat gizi makro, dan daya tahan jantung paru. Hasil penelitian menunjukkan terdapat peningkatan daya tahan jantung paru atlet sepak bola sesudah diberikan maltodekstrin $(51,05 \pm 3,160$ menjadi $51,60 \pm 3,286 \mathrm{~mL} / \mathrm{kg} \mathrm{BB} /$ menit $)(p=0,001)$. Peningkatan daya tahan jantung paru pada kelompok perlakuan $(0,55 \pm 0,126 \mathrm{~mL} / \mathrm{kg} \mathrm{BB} / \mathrm{menit})$ lebih tinggi dari pada kelompok kontrol $(0,18 \pm 0,031 \mathrm{~mL} / \mathrm{kg} \mathrm{BB} /$ menit) dengan nilai $p=0,02$. IMT, persentase lemak tubuh, BMR, asupan mineral dan zat gizi makro tidak berkorelasi dengan daya tahan jantung paru. Disimpulkan bahwa pemberian maltodekstrin sebanyak $4 \times 18 \mathrm{~g}$ dalam $4 \times 300 \mathrm{~mL}$ minuman elektrolit meningkatkan daya tahan jantung paru atlet sepak bola selama latihan.

Kata kunci: maltodekstrin, daya tahan jantung paru, atlet sepak bola 


\section{PENDAHULUAN}

S epak bola merupakan olahraga yang bersifat endurance, karena olahraga tersebut berdurasi waktu yang cukup lama yaitu $2 \times 45$ menit waktu normal. Masyarakat umum mengganggap sepakbola sebagai olahraga yang bertujuan untuk rekreasi, meningkatkan kebugaran, dan mencapai prestasi. Sepakbola yang bertujuan untuk mencapai prestasi harus ditunjang dengan kondisi fisik yang bagus. ${ }^{1}$

Kondisi fisik yang harus dimiliki antara lain kekuatan, daya tahan, daya tahan otot, kecepatan, kelentukan, keseimbangan, kelincahan, koordinasi, ketepatan dan reaksi. Kondisi fisik yang paling penting dalam sepak bola adalah daya tahan, yang digunakan atlet untuk menjalani waktu pertandingan yang lama (2x45 menit waktu normal). ${ }^{2}$

Sepak bola merupakan salah satu olahraga beregu yang membutuhkan ketahanan (endurance) terutama daya tahan jantung paru. Daya tahan jantung paru yang menurun disertai dengan rendahnya kebugaran jasmani dapat menurunkan kecepatan dan keterampilan bermain sepak bola. ${ }^{3}$ Daya tahan jantung paru dapat diketahui dengan cara mengukur kadar $\mathrm{VO}_{2}$ maks yang dicapai. $\mathrm{VO}_{2}$ maks merupakan jumlah uptake atau pengambilan oksigen selama melakukan olahraga. ${ }^{4}$ Hasil penelitian yang dilakukan oleh Bergh et al menunjukkan bahwa atlet yang memiliki $\mathrm{VO}_{2}$ maks sebesar 80 $\mathrm{mL} / \mathrm{kg} \mathrm{BB} /$ menit dapat berlari $5000 \mathrm{~m}$ lebih cepat dibandingkan dengan atlet yang hanya memiliki $\mathrm{VO}_{2}$ maks sebesar $40 \mathrm{~mL} / \mathrm{kg}$ $\mathrm{BB} /$ menit. ${ }^{5} \mathrm{Hal}$ ini berarti semakin tinggi $\mathrm{VO}_{2}$ maks maka semakin baik pula daya tahan jantung paru, sehingga atlet cabang olahraga endurance akan memiliki prestasi yang lebih baik. 6

Status gizi normal dan asupan gizi yang seimbang dapat menunjang daya tahan jantung paru yang optimal. ${ }^{7}$ Hasil penelitian yang dilakukan oleh Widiastuti dkk pada subjek sebanyak 26 atlet menunjukkan bahwa 22 atlet $(86,4 \%)$ mengonsumsi energi sesuai dengan kebutuhan memiliki nilai $\mathrm{VO}_{2}$ maks yang telah memenuhi standar dan sisanya sebanyak 4 orang atlet $(15,4 \%)$ mengonsumsi energi kurang dari kebutuhan mereka memiliki nilai $\mathrm{VO}_{2}$ maks kurang dari standar. ${ }^{8}$ Asupan zat gizi yang seimbang mempengaruhi penampilan seorang atlet pada saat bertanding. ${ }^{9}$ Konsumsi energi dan zat gizi yang kurang atau melebihi dari total kebutuhan pada umumnya akan memberikan efek yang kurang baik terhadap fungsi fisiologis tubuh. ${ }^{10}$

Di satu sisi, asupan zat gizi yang seimbang telah diketahui dapat mempengaruhi penampilan seorang atlet baik saat bertanding maupun saat latihan. Disisi lain pengaturan dan pemantauan asupan gizi seimbang termasuk pemilihan nutrisi yang tepat untuk atlet masih jarang, bahkan masih belum dilaksanakan secara optimal sehingga seringkali terjadi salah persepsi mengenai nutrisi yang tepat untuk memenuhi kebutuhan atlet. Misalnya minuman elektrolit yang berperan dalam rehidrasi cairan dan elektrolit cenderung digunakan sebagai sumber energi bagi atlet selama melaksanakan latihan.

Maltodekstrin $\left(\mathrm{C}_{5} \mathrm{H}_{10} \mathrm{O}_{5}\right) \mathrm{n} \cdot \mathrm{H}_{2} \mathrm{O}$ merupakan sakarida dengan berat molekul antara polisakarida dan oligosakarida dengan $\mathrm{DE}$ (dextrose equivalent) kurang dari 20 yang secara fisik tampak sebagai bubuk berwarna putih. Maltodekstrin bersifat larut dalam air, memiliki flavor dan sensasi mulut (mouthfeel) yang lembut. ${ }^{11}$ Beberapa penelitian menyatakan bahwa konsumsi larutan polimer glukosa (maltodekstrin) akan mempercepat laju pengosongan lambung sehingga tidak akan mengakibatkan ketidaknyamanan pada lambung selama atlet melakukan latihan. ${ }^{12}$ Melihat manfaat maltodekstrin tersebut, maka perlu adanya pemanfaatan maltodekstrin sebagai komponen tambahan dalam minuman elektrolit sehingga dapat menunjang dan meningkatkan daya tahan tubuh atlet selama melakukan latihan.

Sebagai alternatif pemenuhan kebutuhan energi atlet selama latihan dapat dilakukan dengan memanfaatkan minuman elektrolit yang mengandung karbohidrat. Pemberian minuman elektrolit yang mengandung karbohidrat selain mampu menyediakan energi yang cukup untuk menunjang daya tahan latihan yang optimal, juga mampu mengembalikan cairan dan elektrolit yang hilang selama latihan. Pemberian karbohidrat pada atlet perlu memperhatikan jenis karbohidrat, dan yang dipilih adalah jenis karbohidrat yang memiliki osmolalitas rendah seperti larutan polimer glukosa (maltodekstrin) yang dapat diberikan sebelum dan selama latihan. 


\section{METODE PENELITIAN}

Penelitian ini termasuk dalam penelitian eksperimen semu (Quasi eksperimental) dengan menggunakan crossover design. Penelitian ini dilaksanakan di Stadion Jatidiri Semarang untuk pelaksanaan tes daya tahan jantung paru dan Laboratorium Teknologi Hasil Pertanian Universitas Brawijaya Malang untuk pengujian kadar elektrolit. Penelitian dilaksanakan pada bulan April sampai bulan Mei 2015. Sebelum pengambilan data, peneliti mengajukan permohonan kepada dewan komisi etik di Fakultas Kedokteran Universitas Diponegoro untuk menilai kelayakan motode penelitian yang digunakan.

\section{Pelaksanaan Penelitian Pendahuluan}

Peneliti melakukan penelitian pendahuluan terhadap subjek yang sama pada satu bulan sebelum penelitian dilaksanakan. Penelitian pendahuluan dilakukan bertujuan untuk mengetahui status hidrasi atlet, yaitu untuk mengetahui jumlah cairan yang dibutuhkan atlet selama melakukan latihan. Prosedur penelitian pendahuluan yaitu peneliti mengukur berat badan atlet sebelum berlatih, kemudian memberikan minuman mineral yang biasa dikonsumsi atlet ketika latihan, dan kemudian setelah latihan atlet diukur berat badannya. Data tersebut kemudian dimasukkan ke dalam rumus cara menghitung kebutuhan cairan atlet yaitu (Berat badan awal - Berat badan setelah latihan) + Jumlah asupan cairan selama latihan $+500 \mathrm{~mL}$. Kemudian hasil itulah yang digunakan sebagai dasar untuk mengetahui jumlah cairan yang dibutuhkan atlet selama latihan pada saat penelitian berlangsung.

\section{Penentuan Subjek Penelitian}

Subjek penelitian ditentukan dengan menggunakan teknik pengambilan sampel dengan metode purposive sampling yaitu dilakukan dengan cara menentukan sampel dengan mempertimbangkan kriteria-kriteria tertentu (ekslusi dan inklusi) yang telah dibuat terhadap subjek yang sesuai dengan tujuan penelitian. Subjek pada kelompok kontrol juga berlaku sebagai subjek pada kelompok perlakuan, dengan kata lain subjek pada kelompok kontrol dan kelompok perlakuan adalah orang yang sama.
Subjek dalam penelitian ini dipilih berdasarkan kriteria sebagai berikut (inklusi):

a. Terdaftar sebagai atlet sepak bola PPLP Jawa Tengah

b. Tidak sedang mengalami cidera

c. Aktif mengikuti latihan (minimal $75 \%$ kehadiran setiap bulan)

d. Tidak mengkonsumsi suplemen dan minuman berenergi selama penelitian berlangsung

e. Sebelum melaksanakan tes, tekanan darah atlet normal

f. Bersedia menjadi subjek penelitian dengan menandatangani informed consent.

Kriteria eksklusi sampel penelitian antara lain :

a. Subjek akan dikeluarkan dari penelitian jika mengundurkan diri dari penelitian dan sakit.

b. Subjek memiliki riwayat diabetes mellitus.

c. Memiliki riwayat penyakit cardiorespiratory (ISPA, asma, TB, CHF, PPOK, dll).

\section{Formulasi Minuman Elektrolit dan Minuman Elektrolit Berkarbohidrat}

Minuman elektrolit yang digunakan dalam penelitian ini adalah minuman elektrolit bermerek cheers yang sudah dikomersilkan (peneliti membeli di distributor). Volume cairan yang terdapat pada minuman elektrolit sebanyak $300 \mathrm{~mL}$ dan komposisi kandungan elektrolitnya yaitu $40,6 \mathrm{mg} \mathrm{Na}^{+}, 4,0 \mathrm{mg} \mathrm{K}^{+}, 31,2$ $\mathrm{mg} \mathrm{Ca}^{2+}$, dan $80,2 \mathrm{mg} \mathrm{Mg}^{2+}$. Maltodekstrin yang digunakan adalah maltodekstrin dari hasil hidrolisis pati yang sudah dikomersilkan (peneliti membeli di distributor). Maltodekstrin yang akan digunakan yaitu sebanyak $18 \mathrm{~g}$ dalam $300 \mathrm{~mL}$ cairan (mengandung 6-8 g dalam $100 \mathrm{~mL}$ cairan sesuai teori). Minuman elektrolit kemudian dicampur dengan maltodekstrin dan dihomogenisasi. Kandungan elektrolit pada minuman hasil homogenisasi tersebut terdiri dari 0,189 $\mathrm{mg} \mathrm{Na}^{+}, 0,165 \mathrm{mg} \mathrm{K}^{+}, 0,216 \mathrm{mg} \mathrm{Ca}^{2+}$, dan $0,00042 \mathrm{mg} \mathrm{Mg}^{2+}$ (pengujian kadar elektrolit tersebut menggunakan Atomic Absorption Spectroscopy di Laboratorium Teknologi Hasil Pertanian Universitas Brawijaya Malang).

Pada kelompok kontrol diberikan intervensi berupa minuman elektrolit sebanyak $4 \times 300 \mathrm{~mL}$ pada interval tertentu (menit 30, 60, 90 dan 120) 
selama latihan berlangsung. Pada kelompok perlakuan diberikan intervensi berupa minuman elektrolit sebanyak $4 \times(300 \mathrm{~mL}$ yang ditambah $18 \mathrm{~g}$ maltodekstrin) pada interval tertentu (menit $30,60,90$ dan 120) selama latihan berlangsung.

\section{Pengujian Kadar Elektrolit pada Minuman Elektrolit Berkarbohidrat Hasil Formulasi}

Pengujian kadar elektrolit dilakuakan di Laboratorium Teknologi Hasil Pertanian Universitas Brawijaya Malang pada bulan Desember tahun 2014. Pengujian kadar elektrolit tersebut menggunakan Atomic Absorption Spectroscopy. Kandungan elektrolit pada minuman hasil homogenisasi tersebut terdiri dari $0,189 \mathrm{mg} \mathrm{Na}^{+}, 0,165 \mathrm{mg} \mathrm{K}^{+}, 0,216$ $\mathrm{mg} \mathrm{Ca}^{2+}$, dan 0,00042 $\mathrm{mg} \mathrm{Mg}^{2+}$.

\section{Metode Pengujian Daya Tahan Jantung Paru}

Daya tahan jantung paru dapat diketauhi melalui kapasitas $\mathrm{VO}_{2}$ maks yang dapat diukur menggunakan multistage test. Tes ini terdiri dari 23 level dengan durasi pelaksanaan untuk setiap level-nya sekitar 1 menit. Setiap level terdiri dari serangkaian tes lari dengan jarak 20 meter. Tes dimulai dengan kecepatan lari 8,5 $\mathrm{km} / \mathrm{jam}$ dan meningkat $0,5 \mathrm{~km} / \mathrm{jam}$ untuk setiap level. Softfile multistage test ketika berbunyi "beep" satu kali mengindikasikan akhir untuk setiap satu putaran lari sedangkan bunyi "beep" tiga kali menandakan dimulainya level yang berikutnya.

Prosedur pelaksanaan multistage test adalah sebagai berikut:13

a. Subjek berlari dengan jarak 20 meter dan jika subjek tiba di akhir setiap putaran sebelum bunyi "beep", maka subjek harus menunggu bunyi "beep" untuk kemudian melanjutkan berlari pada putaran berikutnya.

b. Subjek harus tetap menjaga kecepatan berlarinya sesuai dengan irama bunyi "beep" dan jika subjek tidak mampu lagi mengikuti sebanyak 3 kali bunyi "beep" berturut-turut, maka multistage test berakhir untuk subjek tersebut.

c. Nilai hasil multistage test kemudian dikonversikan kedalam Tabel perhitungan prediksi $\mathrm{VO}_{2}$ maks.

\section{Pelaksanaan penelitian dan pengambilan data penelitian}

Penilitian dilakukan selama 6 minggu, dengan rincian untuk kelompok kontrol pada minggu ke-1 pengukuran yang dilakukan meliputi berat badan, tinggi badan, IMT, persentase lemak tubuh, BMR, asupan mineral dan zat gizi makro, dan daya tahan jantung paru pre menggunakan multistage test. Minggu ke-2 dan ke-3 dilakukan pengambilan data post untuk kelompok kontrol. Data yang diambil yaitu daya tahan jantung paru setelah atlet malakukan latihan selama 120 menit. Pada saat latihan atlet diberi intervensi berupa $4 \times 300 \mathrm{~mL}$ minuman elektrolit pada menit ke 30,60, 90, dan 120. Pengambilan data asupan nutrisi menggunakan metode recall 1x24 jam pada saat atlet selesai makan malam. Pengambilan data post pada kelompok kontrol dilakukan pengulangan sebanyak 3 kali dengan interval jeda masing-masing 3 hari. Setelah pengambilan data pada kelompok kontrol, subjek diberikan waktu istirahat selama satu minggu. Periode waktu ini digunakan sebagai wash out period.

Minggu ke-4 dilakukan pengambilan data pre untuk kelompok perlakuan. Data yang diambil yaitu tes daya tahan jantung paru atlet dengan menggunakan multistage test. Minggu ke-5 dan ke-6 dilakukan pengambilan data post untuk kelompok perlakuan. Data yang diambil yaitu daya tahan jantung paru setelah atlet malakukan latihan selama 120 menit. Intervensi diberikan selama latihan, berupa $4 \times(300 \mathrm{~mL}$ elektrolit yang ditambah $18 \mathrm{~g}$ maltodekstrin) pada menit ke 30, 60, 90, dan 120 .

Pengambilan data asupan nutrisi menggunakan metode recall $1 \times 24$ jam pada saat atlet selesai makan malam. Pengambilan data post pada kelompok perlakuan dilakukan pengulangan sebanyak 3 kali dengan interval jeda masing-masing 3 hari. Sebelum melakukan latihan dan tes daya tahan jantung paru, atlet diambil data tekanan darah. Hal itu bertujuan untuk mencegah terjadinya bahaya kematian mendadak, dikarenakan tes daya tahan jantung paru merupakan tes kemampuan aerobik yang mengharuskan atlet pada saat melakukan tes benar-benar dalam keadaan batas kemapuan maksimal. 


\section{Analisis Data}

Analisis univariat digunakan untuk mendeskripsikan semua variabel, yang bertujuan untuk mengetahui frekuensi dan mempermudah analisis selanjutnya. Data hasil recall 1x24 jam dianalisis terlebih dahulu menggunakan Nutrisurvey 2004 for Windows untuk mengetahui asupan kalori dan zat gizi subjek penelitian. Data disajikan dalam bentuk Tabel. Analisis bivariat dilakukan untuk mengetahui adanya perbedaan daya tahan jantung paru atlet sepak bola sebelum dan sesudah diberikan maltodekstrin pada kelompok kontrol dan perlakuan. Uji normalitas data dengan Shapiro-wilk menunjukkan data tidak berdistribusi normal, sehingga analisis data menggunakan uji non parametrik yaitu uji Wilcoxon. ${ }^{14}$ Uji bivariat juga dilakukan untuk mengetahui adanya perbedaan daya tahan jantung paru atlet sepak bola antara kelompok kontrol dan perlakuan. Uji normalitas data menunjukkan bahwa data tidak berdistribusi normal, sehingga analisis data menggunakan uji non parametrik yaitu uji Mann Whitney. Hasil analisis dikatakan signifikan (berpengaruh) jika nilai peluang kurang dari 5 persen $(p<0,05)$. Uji korelasi untuk mengetahui hubungan antara variabel dependen dengan variabel yang diduga mengganggu menggunakan uji Spearman, karena uji normalitas menunjukkan data berdistribusi tidak normal. Hasil analisis dikatakan signifikan (berpengaruh) jika nilai $p<$ 0,05 .

\section{HASIL}

Subjek dalam penelitian ini adalah atlet PPLP sepak bola Jawa Tengah yang berjumlah 17 orang. Semua subjek dalam penelitian ini masih duduk di bangku SMA dengan rentang usia berkisar antara 16-18 tahun. Berat badan subjek berkisar antara $52 \mathrm{~kg}-73,9 \mathrm{~kg}$. Karakteristik subjek penelitian selengkapnya disajikan pada Tabel 1.

Hasil pengamatan menyatakan bahwa subjek penelitian rata-rata memiliki IMT yang normal, berkisar antara 19,4 - 24,6 kg/m². Persentase lemak tubuh subjek berkisar antara 9,8 - 22,9 persen dan kebutuhan energi basal subjek berkisar antara 1005,0 - 1450,0 kkal. Persentase lemak tubuh subjek berkisar antara 9,8 - 22,9 persen. Gambaran asupan energi dan zat gizi subjek penelitian selengkapnya disajikan pada Tabel 2.

Tabel 1

Karakteristik Subjek Penelitian

\begin{tabular}{lccc}
\hline Karakteristik & Rerata $\pm \mathrm{SD}(\mathrm{n}=17)$ & Min & Maks \\
\hline Usia & $17,0 \pm 0,70$ & 16 & 18 \\
Berat Badan $(\mathrm{kg})$ & $64,6 \pm 5,85$ & 52,0 & 73,9 \\
Tinggi Badan $(\mathrm{cm})$ & $173,2 \pm 6,35$ & 160,2 & 183,0 \\
IMT $\left(\mathrm{kg} / \mathrm{m}^{2}\right)$ & $21,8 \pm 1,39$ & 19,4 & 24,6 \\
Persentase Lemak Tubuh (\%) & $19,3 \pm 3,19$ & 9,8 & 22,9 \\
BMR (kkal) & $1701,0 \pm 129,78$ & 1450,0 & 1905,0 \\
\hline
\end{tabular}

Tabel 2

Rerata Asupan Energi dan Zat Gizi Subjek Penelitian

\begin{tabular}{|c|c|c|c|c|c|c|}
\hline \multirow{3}{*}{ Karakteristik } & \multicolumn{6}{|c|}{ Kelompok $(n=17)$} \\
\hline & \multicolumn{3}{|c|}{ Kontrol } & \multicolumn{3}{|c|}{ Perlakuan } \\
\hline & Rerata + SD & Min & Maks & Rerata + SD & Min & Maks \\
\hline Energi (kkal) & $3272,9 \pm 811,14$ & 1937,4 & 4504,6 & $2882,1 \pm 752,90$ & 1749,7 & 4584,3 \\
\hline Karbohidrat (g) & $430,4 \pm 146,14$ & 177,6 & 668,7 & $425,2 \pm 137,09$ & 201,0 & 723,1 \\
\hline Protein (g) & $111,7 \pm 26,64$ & 66,2 & 155,4 & $107,2 \pm 26,19$ & 58,6 & 155,6 \\
\hline Lemak (g) & $110,5 \pm 33,22$ & 60,4 & 159,9 & $105,9 \pm 27,41$ & 58,7 & 142,5 \\
\hline Natrium (mg) & $1213,3 \pm 613,11$ & 343,8 & 2793,2 & $1024,4 \pm 504,75$ & 605,8 & 2130,9 \\
\hline Kalsium (mg) & $766,8+444,66$ & 324,5 & 2056,8 & $1003,7+680,23$ & 277,3 & 2891,9 \\
\hline Kalium (mg) & $2932,8+918,08$ & 1483,8 & 4570,3 & $2778,6+1532,03$ & 1354,3 & 7491,4 \\
\hline Magnesium (mg) & $393,8 \pm 101,69$ & 212,5 & 502,9 & $366,7 \pm 138,07$ & 175,5 & 763,4 \\
\hline
\end{tabular}


Tabel 3

Peningkatan Daya Tahan Jantung Paru Atlet Sesudah Pemberian Maltodekstrin

\begin{tabular}{lcl}
\hline Daya Tahan Jantung Paru & Rerata \pm SD $(\mathrm{mL} / \mathrm{kg} \mathrm{BB} / \mathrm{menit})$ & Nilai $\mathrm{p}$ \\
\hline Sebelum & $51,05 \pm 3,160$ & $0,0001^{*}$ \\
Sesudah & $51,60 \pm 3,286$ & \\
\hline
\end{tabular}

*perbedaan rerata signifikan pada taraf 0.05

Tabel 4

Perbedaan Daya Tahan Jantung Paru Atlet pada Kelompok Kontrol dan Kelompok Perlakuan

\begin{tabular}{lcccc}
\hline Kelompok & $\begin{array}{c}\text { Daya Tahan Jantung Paru }(\mathrm{mL} / \mathrm{kg} \mathrm{BB} / \mathrm{menit}) \\
\text { Sebelum }\end{array}$ & $\begin{array}{c}\text { Selisih }(\Delta) \text { Daya } \\
\text { Tahan Jantung Paru } \\
(\mathrm{mL} / \mathrm{kg} \mathrm{BB} / \text { menit })\end{array}$ & Nilai $\mathrm{p}$ \\
\hline Kontrol & $46,88 \pm 1,713$ & $47,06 \pm 1,682$ & $0,18 \pm 0,031$ & $0,02^{*}(\#)$ \\
\hline Perlakuan & $51,05 \pm 3,160$ & $51,60 \pm 3,286$ & $0,55 \pm 0,126$ & \\
\hline
\end{tabular}

(\#) Uji Wilcoxon (perbandingan $\Delta$ daya tahan jantung paru)

Tabel 5

Hasil Analisis Uji Korelasi antara Variabel yang Dicurigai Mengganggu terhadap Daya Tahan Jantung Paru

\begin{tabular}{lcc}
\hline Variabel yang Dicurigai Mengganggu & $\mathrm{R}$ & Nilai $\mathrm{p}^{\#}$ \\
\hline IMT (kg/m²) & $-0,014$ & 0,47 \\
Persentase Lemak Tubuh (\%) & $-0,033$ & 0,43 \\
BMR (kkal) & $-0,058$ & 0,37 \\
Energi (kkal) & 0,003 & 0,50 \\
Karbohidrat (g) & 0,043 & 0,40 \\
Protein (g) & 0,029 & 0,43 \\
Lemak (g) & $-0,205$ & 0,12 \\
Natrium (mg) & 0,134 & 0,22 \\
Kalsium (mg) & 0,018 & 0,46 \\
Kalium (mg) & 0,212 & 0,11 \\
Magnesium (mg) & 0,199 & 0,13 \\
\hline \#Uj Korelasi Spearman (antara variabel yang dicurigai mengganggu terhadap variabel daya tahan jantung paru) \\
* Signifikan pada taraf 0,05
\end{tabular}

\section{Peningkatan daya tahan jantung paru atlet sesudah pemberian maltodekstrin}

Pengukuran daya tahan jantung paru menggunakan multistage test, yaitu atlet melakukan tes lari bolak-balik dengan jarak 20 meter dan mengikuti irama tes melalui suara. Atlet dinyatakan selesai dan dicatat oleh tester apabila atlet sudah tidak kuat lagi mengikuti irama tes. Hasil dari pengukuran multistage test kemudian dikonversikan menggunakan Tabel prediksi $\mathrm{VO}_{2}$ maks untuk mengetahui peningkatan daya tahan jantung paru atlet sebelum diberi maltodekstrin dan setelah diberi maltodekstrin.

Pada Tabel 3 menunjukkan bahwa pada kelompok perlakuan terdapat peningkatan $(p=0,0001)$ daya tahan jantung paru atlet sesudah diberi maltodekstrin $(51,60 \pm 3,286$ $\mathrm{mL} / \mathrm{kg} \mathrm{BB} /$ menit).

Perbedaan daya tahan jantung paru atlet pada kelompok kontrol dan kelompok perlakuan

Hasil uji statistik dengan Mann-Whitney test menunjukkan bahwa terdapat perbedaan peningkatan daya tahan jantung paru yang signifikan antara kelompok kontrol dengan kelompok perlakuan (nilai $p=0,02$ ). Pada Tabel 4 menyatakan bahwa baik pada kelompok kontrol maupun kelompok subjek yang diberikan minuman elektrolit + maltodekstrin (kelompok perlakuan) menunjukkan peningkatan daya tahan jantung paru. Hasil penelitian juga menyatakan bahwa peningkatan daya tahan 
jantung paru kelompok perlakuan menunjukkan angka yang lebih tinggi dibandingkan dengan kelompok kontrol.

\section{Hasil analisis uji korelasi antara variabel yang dicurigai mengganggu terhadap daya tahan janjung paru}

Pada Tabel 5 menunjukkan bahwa variabel yang dicurigai mengganggu IMT, persentase lemak tubuh, BMR, asupan natrium, kalsium, magnesium, kalium, energi, karbohidrat, protein, dan lemak) tidak menunjukkan adanya korelasi terhadap daya tahan jantung paru (nilai $p>$ $0,05)$.

Hasil analisis uji korelasi menggunakan Spearman pada variabel pengganggu (IMT, persentase lemak tubuh, BMR, dan asupan natrium, kalsium, magnesium, kalium, energi, karbohidrat, protein, dan lemak) tidak ada korelasi dengan daya tahan jantung paru.

\section{BAHASAN}

Penilaian asupan makanan pada subjek penelitian menggunakan metode recall 24 jam, yang meliputi asupan energi, zat gizi makro (karbohidrat, protein, dan lemak) serta asupan mineral (natrium, kalsium, kalium, dan magnesium). Tabel diatas menyatakan bahwa asupan energi dan zat gizi pada kelompok kontrol dan kelompok perlakuan menunjukkan nilai yang berbeda, meskipun kedua kelompok tersebut terdiri dari subjek yang sama. Hal ini disebabkan perbedaan menu makanan yang dikonsumsi pada saat subjek penelitian menjadi kelompok kontrol dan kelompok perlakuan. Subjek penelitian selama berada di asrama selalu disediakan menu makanan katering, namun konsumsi makanan subjek penelitian masih belum sepenuhnya mampu dikontrol terutama saat subjek berada di sekolah. Subjek seringkali bosan dan memilih untuk mengkonsumsi makanan diluar menu yang disediakan katering, sehingga jumlah makanan yang dikonsumsi juga akan berbeda.

Subjek pada kelompok perlakuan mengalami peningkatan daya tahan jantung paru sebesar $51,60 \pm 3,286 \mathrm{~mL} / \mathrm{kg} \mathrm{BB} /$ menit. Hal ini didukung dengan teori yang menyatakan bahwa pemberian karbohidrat sebelum dan sesudah latihan dapat meningkatkan performa atlet pada olahraga yang bersifat aerobik. ${ }^{15}$ Penelitian lain pada atlet pencak silat yang diberi suplementasi karbohidrat+lemak+protein juga menunjukkan hasil yang signifikan terhadap kadar glukosa darah. ${ }^{16}$ Pustaka lain menjelaskan bahwa pada saat melakukan latihan fisik, tubuh akan membutuhkan sejumlah kation dan anion untuk menjaga keseimbangan elektrolit dan cairan dalam tubuh. Tubuh juga membutuhkan asupan energi, terutama karbohidrat sebagai sumber energi utama untuk meningkatkan performa selama melakukan latihan fisik. Konsumsi karbohidrat selama latihan fisik dapat memperlambat terjadinya kelelahan dengan menurunkan penggunaan simpanan glikogen hati dan mencegah terjadinya hipoglikemia dengan mengontrol kadar gula dalam darah. ${ }^{17}$

Peningkatan daya tahan jantung paru sebesar $0,55 \mathrm{~mL} / \mathrm{kg} \mathrm{BB} /$ menit pada subjek yang telah diberi maltodekstrin sama dengan 2 kali balikan pada level 11 pada multistage test (sekitar 20 detik). Nilai tersebut sangat berarti apabila diaplikasikan dalam pertandingan sepak bola, misalnya pada saat semua pemain dengan kemampuan daya tahan jantung paru yang sama sudah dalam keadaan ambang batas kemampuan, salah satu pemain memilki $\mathrm{VO}_{2}$ maks lebih besar $0,55 \mathrm{~mL} / \mathrm{kg} \mathrm{BB} /$ menit, maka pemain tersebut masih memiliki kemampuan tambahan berlari selama 20 detik.

Peningkatan ini menunjukkan adanya pengaruh pemberian maltodekstrin terhadap daya tahan jantung paru atlet. Hal ini dikaitkan dengan pemberian minuman elektrolit + maltodekstrin pada atlet sebanyak $4 \times 300 \mathrm{~mL}$ pada menit ke-30, 60, 90, dan 120 selama latihan. Pemberian dengan interval waktu setiap 30 menit tersebut diduga mampu memberikan pasokan energi yang cukup selama latihan. Pasokan energi tersebut digunakan untuk menunjang kapasitas kerja jantung dan paru sehingga daya tahan jantung paru meningkat akibat adanya pemberian maltodekstrin. Maltodekstrin diklasifikasikan ke dalam jenis oligosakarida dengan nilai indeks glikemik tinggi namun menyebabkan peningkatan kadar glukosa darah secara perlahan, sehingga kurva glikemik menunjukkan peningkatan yang stabil untuk periode yang lama. ${ }^{18}$

Berbeda dengan penelitian sebelumnya pada atlet sepeda gunung yang menyatakan bahwa pemberian maltodekstrin tidak berpengaruh terhadap denyut nadi dan $\mathrm{VO}_{2}$ maks. Pemberian maltodekstrin pada penelitian 
tersebut dilakukan 20 menit sebelum latihan berlangsung. ${ }^{19}$ Penelitian lain yang dilakukan oleh Febbraio et al pada subjek pria yang melakukan latihan endurance menyatakan bahwa pemberian karbohidrat indeks glikemik tinggi 30 menit sebelum latihan tidak menunjukkan adanya pengaruh yang nyata terhadap denyut nadi dan $\mathrm{VO}_{2}$ maks. ${ }^{20}$

Pada Tabel 4, adanya peningkatan daya tahan jantung paru pada kelompok kontrol setelah diberi minuman elektrolit dikaitkan dengan adanya penyediaan elektrolit yang cukup selama latihan. Magnesium, kalsium, natrium, dan kalium yang terdisosiasi menjadi anion dan kation dalam minuman elektrolit merupakan mineral yang penting bagi keseimbangan cairan dan elektrolit tubuh serta berperan sebagai kofaktor berbagai proses metabolisme, termasuk metabolisme energi. Mineral tersebut dapat mengoptimalkan proses metabolisme sehingga dapat meningkatkan pasokan energi dan akan menunjang performa latihan dengan durasi yang lebih panjang. Pemberian minuman elektrolit secara berkala dengan interval waktu tertentu selama periode latihan mampu menyediakan elektrolit dalam jumlah yang besar sehingga proses metabolisme dapat berjalan dengan baik selama latihan berlangsung. ${ }^{21}$

Energi hasil metabolisme tersebut kemudian akan dimanfaatkan untuk kontraksi otot dalam rangka menunjang performa atlet. Energi dibutuhkan untuk kontraksi otot rangka sehingga atlet dapat melakukan berbagai gerakan, selain itu energi juga dibutuhkan untuk kontraksi otot polos paru dan jantung. Otot polos paru akan berkontraksi sehingga terjadi pertukaran gas di alveoli, sedangkan otot jantung akan berkontraksi untuk memompa darah ke seluruh bagian tubuh. Darah yang mengandung zat gizi dan oksigen tersebut akan ditransportasikan ke seluruh bagian tubuh sehingga dapat menunjang performa atlet dalam melakukan aktivitas fisik yang bersifat aerobik. Magnesium merupakan kation yang tersedia dalam jumlah yang tinggi di intraseluler, berperan penting dalam proses glikolisis dan siklus Krebs, serta menjaga keseimbangan gradien muatan elektrik dalam membran sel otot. Magnesium juga berperan sebagai kofaktor dan aktivator berbagai macam enzim dalam metabolisme energi. ${ }^{22}$
Indeks massa tubuh (IMT) adalah berat badan $(\mathrm{kg})$ yang dibagi dengan tinggi badan $(\mathrm{m})$ dalam kuadrat. IMT merupakan salah satu indikasi untuk mengetahui status gizi seseorang, ${ }^{23}$ dalam hal ini adalah atlet sepak bola. Pada Tabel 5 menunjukkan bahwa IMT tidak berhubungan dengan daya tahan jantung paru $(p=0,92)$, hal ini dikarenakan pada saat penyeleksian atlet PPLP, IMT dijadikan salah satu faktor perhitungan. Atlet dengan IMT yang proporsional diharapkan dapat menunjang kondisi fisik yang optimal dan menunjang prestasi klub, dengan kata lain secara keseluruhan atlet memiliki IMT yang hampir sama. Hal ini serupa dengan penelitian yang dilakukan oleh Wicaksono yang menunjukkan hasil bahwa tidak adanya hubungan yang signifikan antara indeks massa tubuh dengan daya tahan jantung paru. ${ }^{24}$

Asupan energi juga tidak berhubungan dengan daya tahan jantung paru $(P=0,82)$, hal ini serupa dengan penelitian yang dilakukan oleh Ita dengan hasil bahwa tidak terdapat hubungan yang bermakna antara asupan energi dengan $\mathrm{VO}_{2}$ maks. ${ }^{25}$ Karbohidrat merupakan sumber energi utama yang diperlukan untuk membentuk glikoken dalam hati dan otot yang dibutuhkan atlet untuk memenuhi asupan nutrisi. $^{3}$ Hasil dari penelitian ini, karbohidrat tidak berhubungan dengan daya tahan jantung paru $(p=0,22)$. Hal ini serupa dengan penelitian yang dilakukan oleh Pertiwi yang menyebutkan bahwa tidak ada hubungan antara asupan karbohidrat dengan daya tahan jantung paru. ${ }^{26}$

Protein merupakan zat gizi yang digunakan sebagai penyembuhan dan pembentukan otot. ${ }^{27}$ Hasil dari penelitian ini asupan protein tidak mempengaruhi daya tahan jantung paru $(p=0,43)$. Hasil ini serupa dengan penelitian yang dilakukan oleh Kusumawati yang menyebutkan bahwa asupan protein tidak memiliki hubungan yang bermakna dengan daya tahan jantung paru. ${ }^{28}$ Lemak merupakan zat gizi yang menghasilkan sumber energi paling besar dan merupakan sumber energi yang penting untuk kontraksi otot pada olahraga yang bersifat endurance. ${ }^{3}$ Hasil dari penelitian ini menunjukkan lemak tidak mempengaruhi daya tahan jantung paru $(p=0,23)$. Hal ini serupa dengan penelitian yang dilakukan oleh Pertiwi yang menyebutkan tidak ada hubungan antara asupan lemak dengan daya tahan jantung paru. ${ }^{26}$ 
Hasil analisis uji korelasi pada variabel pengganggu (IMT, persentase lemak tubuh, BMR, dan asupan natrium, kalsium, magnesium, kalium, energi, karbohidrat, protein, dan lemak) pada Tabel 5 menunjukkan bahwa tidak ada korelasi dengan daya tahan jantung paru. Hal ini disebabkan faktor yang dapat meningkatkan daya tahan jantung paru atlet adalah latihan yang bersifat endurance. ${ }^{29} \mathrm{Hal}$ ini didukung dengan penelitian yang dilakukan oleh Prativi yang menyebutkan bahwa aktivitas fisik (latihan) berpengaruh terhadap daya tahan jantung paru $(p=0,018) .{ }^{30}$

Latihan fisik yang bersifat endurance mengakibatkan beberapa perubahan sistem kardiorespratori, antara lain: 1) hipertrofi otot jantung, karena volume darah yang mengisi serambi jantung akan semakin banyak, sehingga volume darah yang akan dipompa semakin meningkat, 2) penurunan detak jantung pada saat recovery, 3) peningkatan volume darah yang dipompa oleh jantung yang disebabkan hipertrofi otot jantung dan peningkatan kemampuan kontraksi otot jantung, 4) peningkatan kapasitas total paru-paru, 5) peningkatan volume darah dan hemoglobin yang merupakan parameter penting dalam sistem tarnsport oksigen dan sangat berkorelasi dengan $\mathrm{VO}_{2}$ maks, 6) peningkatan jumlah pembuluh darah kapiler dan hipertrofi otot skeletal yang mengakibatkan peningkatan penyediaan oksigen dan zat gizi ke dalam otot, 7) Peningkatan $\mathrm{VO}_{2}$ maks (tergantung dari volume latihan, jenis program latihan, dan intensitas latihan), 8) peningkatan kemapuan otot jantung dalam memompa darah, 9) peningkatan volume tidal maksimum dan frekuensi pernafasan per menit, 10) kapasitas difusi paru yang lebih tinggi, yang disebabkan adanya peningkatan aliran darah ke paru-paru sehingga akan terjadi peningkatan pertukaran gas pada alvioli paru..$^{29}$

\section{SIMPULAN DAN SARAN}

\section{Simpulan}

Pemberian maltodekstrin sebanyak $4 \times 18 \mathrm{~g}$ dalam $4 \times 300 \mathrm{~mL}$ minuman elektrolit meningkatkan daya tahan jantung paru atlet sepak bola selama latihan sebesar $0,55 \pm 0,126$ $\mathrm{mL} / \mathrm{kg} \mathrm{BB} /$ menit. Peningkatan daya tahan jantung paru pada kelompok perlakuan $(0,55 \pm$ $0,126 \mathrm{~mL} / \mathrm{kg} \mathrm{BB} / \mathrm{menit}$ ) lebih tinggi dari pada kelompok kontrol $(0,18 \pm 0,031 \mathrm{~mL} / \mathrm{kg}$ $\mathrm{BB} /$ menit). IMT, persentase lemak tubuh, BMR, asupan mineral dan zat gizi makro tidak berkorelasi dengan daya tahan jantung paru.

\section{Saran}

Perlu dilakukan penelitian lebih lanjut mengenai pengaruh pemberian minuman elektrolit berkarbohidat (maltodekstrin) terhadap daya tahan jantung paru atlet pada cabang olahraga lain yang bersifat aerobik dan dilakukan penelitian lebih lanjut mengenai pengaruh pemberian maltodekstrin dalam minuman elektrolit terhadap daya tahan jantung paru atlet selama latihan pada interval tertentu (pada menit ke 30,60 dan 90).

\section{UCAPAN TERIMA KASIH}

Penulis mengucapkan terimakasih kepada atlet sepak bola di Pusat Pendidikan dan Latihan Pelajar Jawa Tengah yang telah bersedia menjadi subjek penelitian, enumerator yang telah bersedia membantu peneliti dalam mengumpulkan data penelitian dan Direktorat Jenderal Pendidikan Tinggi (DIKTI) Kementerian Riset, Teknologi dan Pendidikan Tinggi Republik Indonesia atas pendanaan pendidikan selama 2 Tahun menempuh pendidikan di Universitas Diponegoro Semarang melalui Program Beasiswa Pendidikan Pascasarjana Dalam Negeri (BPPDN). Ucapan terima kasih juga penulis sampaikan kepada laboran dan petugas Laboratorium Teknologi Hasil Pertanian Universitas Brawijaya Malang yang telah membantu dalam analisis minuman elektrolit.

\section{RUJUKAN}

1. Muhyi MF. 2008. Meningkatkan Kebugaran Tubuh Melalui Permainan \& Olahraga Sepak Bola. Surabaya: PT Gramedia Widiasarana Indonesia.

2. Sajoto. 1988. Pembinaan Kondisi Fisik dalam Olahraga. FPOK- IKIP SEMARANG

3. Husaini MA, Dadang AP, Anie K, Dangsina M, Didit D. 2002. Gizi Atlet Sepak Bola. Jakarta: Depkes R.I. Dirjen Kesehatan Masyarakat Direktorat Gizi Masyarakat.

4. Hoff J, Wisloff U, Engen LC, Kemi OJ, Helgerud J. Soccer Specific Aerobic Endurance Training. Br J Sport Med. 2002; 36; 218-21. 
5. Bergh U, Ekblom B, Astrand PO.. Oxygen Uptake 'Classical' Versus 'Contemporary' Viewpoints. Med Sci Sports Exerc. 2000;32:7084.

6. Levine $\mathrm{BD} . \mathrm{VO}_{2} \mathrm{MAX}$ : What Do We Know, and What Do We Still Need to Know?. J Physiol . 2008;586 (1); 25-34.

7. Almatsier S. 2002. Prinsip Dasar IImu Gizi. Jakarta: Gramedia Pustaka Utama

8. Widiastuti PA, Kushartanti BMW, Kandarina IBJ. Pola Makan dan Kebugaran Jasmani Atlet Pencak Silat Selama Pelatihan Daerah Pekan Olahraga Nasional XVII Provinsi Bali tahun 2008. Jurnal Gizi Klinik Indonesia. 2009; 6 (1); 13-20.

9. Heather HF, Lisa C, Alan EM. 2006. Endurance and Ultra-Endurance Athletes. In: Practical Applications in Sport Nutrition. Boston: Jones and Bartlett Publisher 360-97.

10. Hasan MS. Kesegaran Jasmani Olahragawan Sepak Bola Pra-pubertas. Jurnal Iptek Olahraga. 2008; 10(3) 188-202.

11. Sadeghi A, Shahidi F, Mortazavi AS, Mahalati NM. Evaluation of Different Parameters Effect on Maltodextrin Production by -Amylase Termamyl 2-x. World Appl. Sci. J. 2008;3 (1); 34-9.

12. Bronkhorst I, Silva L, Freitas L, Martins $M$, Martins $\mathrm{H}$, Malfati $\mathrm{C}$ et al. Vitamin B6 and Maltodextrin Sport Drink Modify Glucose Levels of Elite Mountain Biking Athletes. JEP online. 2014;17(4); 113-21.

13. Coulson M, Archer D. 2009. Practical Fitness Testing: Analysis in Exercise and Sport. London: A\&C Black Publishers, Ltd.

14. Yitnosumarto S. 1993. Percobaan Perancangan, Analisis, dan Interpretasinya. Jakarta: PT. Gramedia Pustaka Utama.

15. Roberts DJ, Tarpey DM, Kass SL, Tarpey JR, Roberts GM. Assessing A Commercially Available Sport Drink on Exogenous Carbohydrate Oxidation, Fluid Delivery and Sustained Exercise Performance. Jissn. 2014; 11 (8); 1-14.

16. Sudargo $T$, Afidah $R$, Freitag $H$, Amalia RR, Triatanti RK et al. Pengaruh Suplementasi Karbohidrat, Lemak, dan Protein Terhadap Kadar Glukosa Darah dan Asam Laktat pada Atlet Pencak Silat. Journal of the Indonesian Nutrition Association. 2012; 35(1): 10-21

17. Daries H. 2012. Nutrition for Sport and Exercise: A Practical Guide. United Kingdom: Willey \& Blackwell.

18. Sapata KB, Fayh APT, de Oliveira AR. Effect of Prior Consumption of Carbohydrate on The Glycaemia and Performance. Rev Bras Med Esporte. 2006;12 (4); 170e-74e.
19. Malfatti CRM, de Laat EF, Soler LT, Bronkhorst IW, Pacheco CV, Funez EIB, et al. Maltodextrin's Effect on The Performance of Elite Mountain Biking Athletes During Simulated Competition and on Power Output at The Ventilatory Threshold. Human Movement. 2011;12 (3); 232-36.

20. Febbraio MA, Keenan J, Angus DJ, Campbell SE, Garnham AP. Preexercise Carbohydrate Ingestion, Glucose Kinetics, and Muscle Glycogen Use: Effect of The Glycemic Index. J Appl Physiol. 2000; 89; 1845-51.

21. Kapsprzak Z, Biernacki J, Nowak A, Zielinski J, Kusy K, Rejewski R. Assessment of Intake of Essensial Nutrients, Vitamins and Minerals and Selected Indices of Nutritional Status in ShortDistance Runners. Studies in Physical Culture and Tourism. 2006; 13; 141-44.

22. Moughan RJ. Role of Micronutrients in Sport and Physical Activity. British Medical Bulletin. 1999; 55 (3); 683-90.

23. Supariasa IDN, Bakri B, Fajar I. 2001. Penilaian Status Gizi. Jakarta: EGC

24. Wicaksono D, Bawono MN. 2014. Hubungan Antara Indeks Massa Tubuh dan Daya Tahan Jantung Paru pada Pemain U-17 SSB Bina Muda. Jurnal Kesehatan Olahraga. 2014; 2(1): 21-28.

25. Ita. 2009. Hubungan Antara Asupan Energi dengan Indeks Massa Tubuh, dan Kapasitas Oksigen Maksimal $\left(\mathrm{VO}_{2}\right.$ maks) Atlet Pada Periode Latihan di Pusat Pelatihan Klub Bola Basket Satria Muda Britama Jakarta. Yogyakarta: Skripsi. Program Studi Gizi Kesehatan Fakultas Kedokteran Universitas Gadjah Mada

26. Pertiwi $A B$, Murbawani EA. 2012. Pengaruh Asupan Makan (Energi, Karbohidrat, Protein, dan Lemak) Terhadap Daya Tahan Jantung Paru $\left(\mathrm{VO}_{2}\right.$ Maks) Atlet Sepak Bola. Semarang: Skripsi. Universitas Diponegoro Semarang

27. Yesis M, Trubo R. 1993. Rahasia Kebugaran dan Pelatihan Olahraga Soviet. Bandung: ITB Bandung

28. Kusumawati M. 2014. Hubungan Antara Pola Konsumsi Protein dan fe dengan Daya Tahan Jantung Paru Atlet Sepak Bola PS. Semen Padang. Yogyakarta: Skripsi. Universitas Gadjahmada

29. Foss ML and Keteyian SJ. 1998. Fox's Physiological Basis For Exercise and Sport $6^{\text {th }}$ Ed. Boston: The McGraw-Hill Companies, Inc

30. Prativi GO. Pengaruh Aktivitas Olahraga terhadap Kebugaran Jasmani. JSSF. 2013;2 (3); 32-36. 